\title{
EXPERIMENTAL WATERSHED FOR REAL TIME FLOW SIMULATION
}

\author{
Shirisha $\mathbf{P}^{1}$, Venkata Reddy $K^{2}$, Deva Pratap ${ }^{3}$ \\ ${ }^{1}$ Research Scholar, NIT Warangal, shirirajp4@gmail.com \\ ${ }^{2}$ Associate Professor, NIT Warangal, kvreddy@nitw.ac.in \\ ${ }^{3}$ Professor, NIT Warangal, deva@nitw.ac.in
}

\begin{abstract}
Availability of fresh water on the Earth is limited and is varied spatially and temporally. Therefore it is necessary to precisely estimate the availability of water resources at a particular area on a spatial and temporal basis. Watershed is the basic scientific unit for understanding the hydrological regime of an area. The advances in geospatial and soft computing methods have increased the simulation capabilities of distributed watershed models. The present study deals with the development of an experimental watershed and preparation of geospatial layers for the watershed which can be useful for estimation of the precise flow parameters on a real time basis using the distributed watershed models. Continuous in-situ measurements improve the accuracy of watershed model forecasts. For this purpose, watershed at Peechara, Warangal District, India is instrumented with rain gauge station, soil moisture recorder and digital water level recorders. Measured hydrologic data in the watershed is obtained at the institute through telemetry. Geospatial layers such as flow direction and flow accumulation are prepared for the watershed. Hydrologic data along with geospatial layers is the major input for the watershed model for real time flow simulations.
\end{abstract}

Keywords: DEM, Flow Accumulation, Real Time Flow, Telemetry, Watershed.

- ***.

\section{INTRODUCTION}

The availability of fresh water on the Earth is limited and is varied spatially and temporally. As the demand for water is increasing day by day, it is necessary to precisely estimate the available water resources at a particular area on spatial and temporal basis. Representing factors that control runoff in a spatially variable manner makes more accurate predictions possible. The key requirement of real-time flood forecasting is based on continuous in-situ measurements of rainfall to improve the accuracy of model forecasts. Spatially distributed parameters derived from soil properties, land use/land cover, topography, and input from radar offer new possibilities for simulating hydrologic response on drainage network scalable from catchment to river basin. Managing water resources, protecting lives and property from flood damage and warning systems can benefit from customized and timely hydrologic prediction. Distributed parameter watershed models, which are physics-based, offer distinct advantages over conceptual rainfall-runoff models. Distributed models better represent spatial variability of factors that control runoff enhancing the predictability of hydrologic process.

A well instrumented experimental watershed has to be developed to demonstrate the capability of the upgraded distributed watershed model in precise and real time simulation of flow parameters. Many developed countries are also developing the experimental watersheds with complete instrumentation for measuring the weather and hydrologic parameters and to use the data for verification of watershed modelling systems. From the research studies, it is seen that, developed countries established the radar and other sensor based weather and hydrologic measuring systems in the watersheds to obtain the accurate and real time weather and hydrologic database.

\section{LITERATURE REVIEW}

For simulation of flow parameters in real time, the observed meteorological and flow data need to be transmitted through different means of data communication which include telephone, wireless and network of telemetry stations. Vieux (2002) developed a real-time distributed hydrologic model which incorporates routing of unsteady flow through channel and overland elements comprising a drainage network. It provides high resolution runoff estimation for management of water from small watersheds to river basin scale. Precipitation measurements used for real-time flood forecasting include telemetry, weather radar and satellite monitoring systems. AlSabhan et al (2003) introduced new web-based real-time model. Gracia (2001) discussed the integration of real-time hydro meteorological data collection networks with meteorological forecasts and pluviometric information from remote sensing provides instruments for flood forecasting and protection. Young (2002) discussed various advances in realtime flood forecasting. Ashish et.al (2013) reviewed nine commonly used, well documented and continuously updated watershed scale hydrologic models. Modular design, fully distributed and physically-based model is available to simulate several hydrological processes with minimum data requirement. Weather research and forecasting (WRF) model is integrated with the probability distribution model (PDM) to make real-time flow forecasts in small catchments. 


\section{METHODOLOGY}

In the present paper, the methodology for setting up an experimental watershed for real-time flow simulations is presented. Methodology adopted in the study is given below in Figure 1.

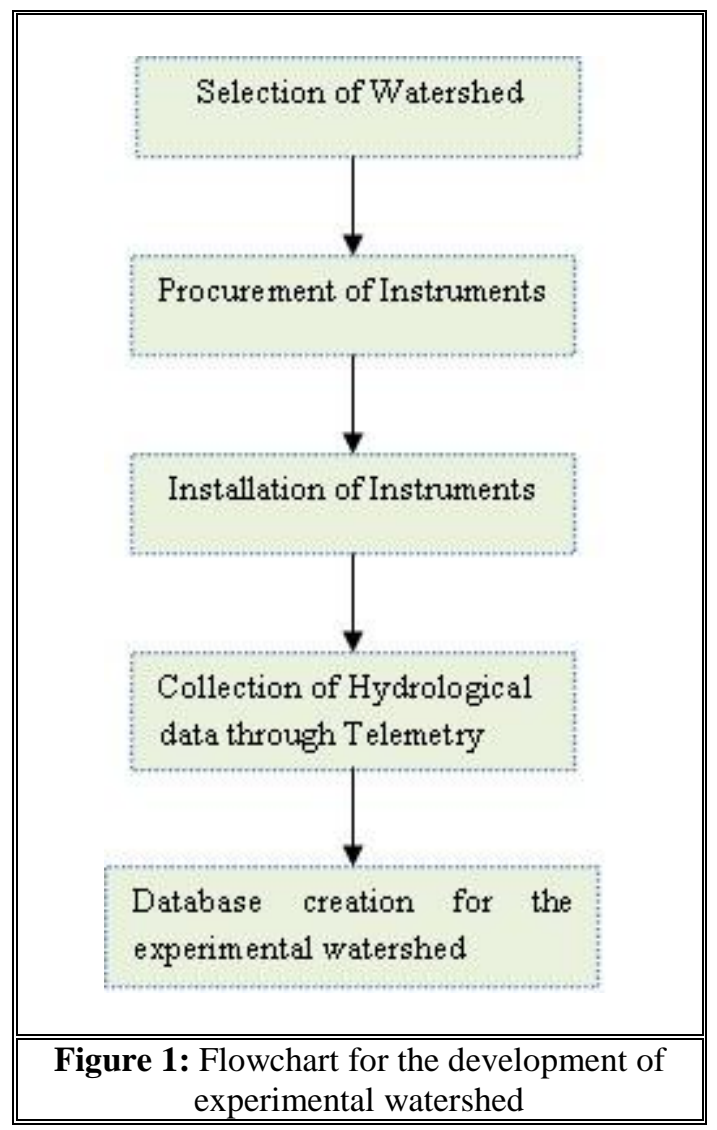

\section{STUDY AREA AND DATABASE}

\section{Watershed Description:}

Peechara Experimental Watershed is being established to investigate hydrologic processes in Peechara, Dharmasagar mandal, Warangal District, Telangana and is approximately $26 \mathrm{~km}$ from Warangal city as shown in Error! Reference source not found.

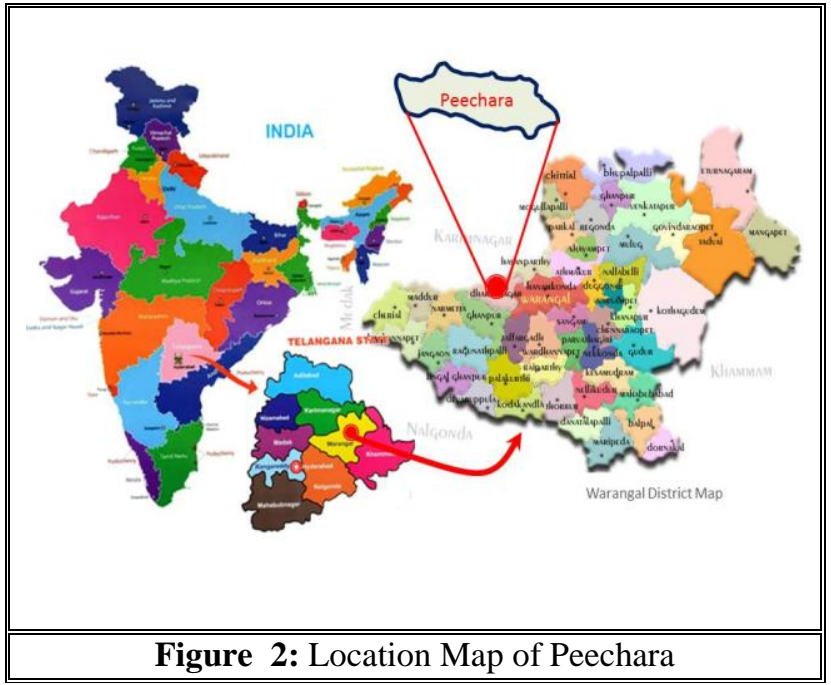

The experimental watershed is delineated with an area of $12.5 \mathrm{~km}^{2}$ from $448 \mathrm{~m}$ to $382 \mathrm{~m}$ elevation. Major drainage system and tributaries of Peechara Watershed belong to Godavari. The Habitats are Kondapur, Peechara and Kannaram. The population of watershed is 2944 and it consists of 2 Grama Panchayats (Kondapur \& Peechara).

\section{Climate:}

The average normal annual rainfall of this watershed is about $784.60 \mathrm{~mm}$. Out of which $70 \%$ of rains are received during south-west monsoon (Jun-Sept) and July and August being the peak rainy months. The relative humidity $(\mathrm{RH})$ is generally high during South- West monsoon season. The rest of the year is generally dry. The climate of the mandal is characterized by hot summer to cold winter with temperature touching $40^{\circ} \mathrm{C}$ in April and May, $22^{\circ} \mathrm{C}$ to $23^{\circ} \mathrm{C}$ in December and January.

\section{Geology and Soils:}

The oldest formations are represented by Archaean rocks which include Older Metamorphics and Peninsular Gneissic Complex. The soils in the area can be divided into red soils, black soils, loams and sandy loams.

\section{DEM:}

As a contribution from METI and NASA to the Global Earth Observation System of Systems (GEOSS), ASTER (Advanced Spaceborn Thermal Emission and reflection radiometer) Global DEM V2 data are available free of charge to users worldwide from USGS login portal. ASTER GDEM covers the study area with great accuracy to about $7 \sim 14 \mathrm{~m}$. GDEM maintains the GeoTIFF format and the gridding with $30 \mathrm{~m}$ postings. DEM is generated for the watershed and the elevations vary from $373 \mathrm{~m}$ to $498 \mathrm{~m}$ as shown in Figure 3. 


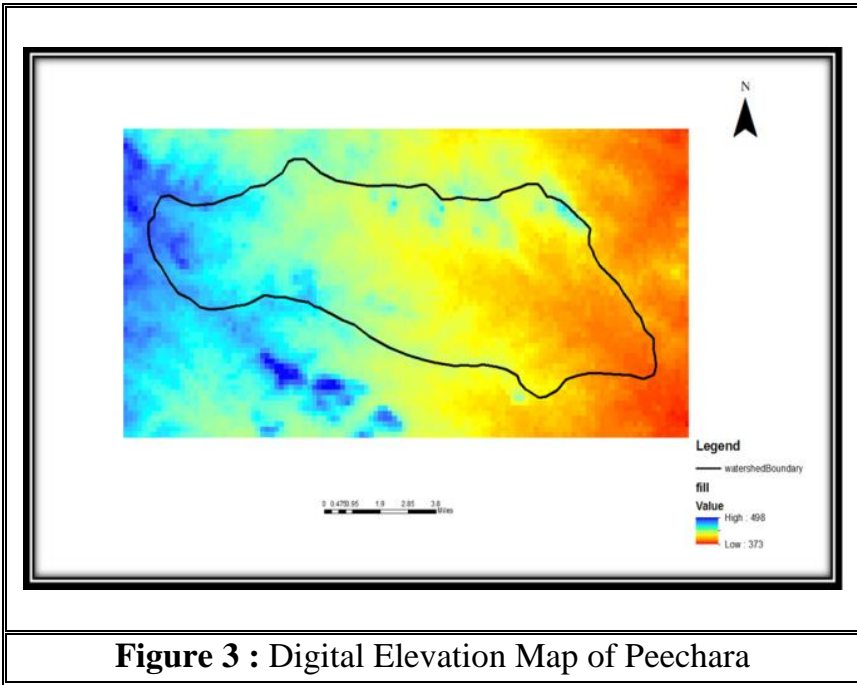

\section{Flow Direction:}

The flow direction map is derived from ArcGIS as shown in Figure 4. The direction of flow from every cell in the raster is found out with the Flow Direction tool. Here surface is given as input and the output is a raster showing the direction of flow out of each cell. There are eight valid output directions relating to the eight adjacent cells into which the flow would travel. This approach is commonly referred to as an eightdirection (D8) flow model. To obtain the highest quality flow direction map, a stream network delineated from a Digital Elevation Model (DEM) is burned in. The direction of flow is determined by the direction of steepest descent, or maximum drop, from each cell and is calculated as follows:

Maximum drop $=$ change in $\mathrm{z}$-value $/$ distance $* 100$

The distance is calculated between cell centers. Therefore, if the cell size is 1 , the distance between two orthogonal cells is 1 , and the distance between two diagonal cells is 1.414 (the square root of 2). If the maximum descent to several cells is the same, the neighbourhood is enlarged until the steepest descent is found. When a direction of steepest descent is found, the output cell is coded with the value representing that direction. To obtain an accurate representation of flow direction across a surface, the sinks are filled before using a flow direction raster.

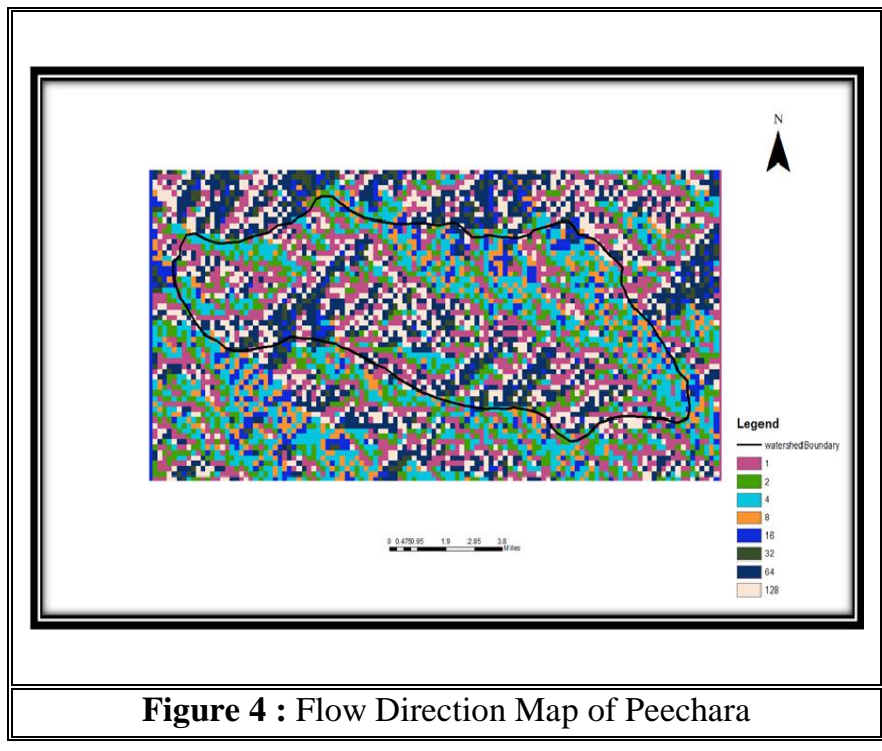

\section{Flow Accumulation:}

The flow accumulation map is obtained from ArcGIS as shown in Figure 5. Flow Accumulation tool is used, in which the input is flow direction raster and the output is Flow accumulation raster. The output raster will always be uncompressed. The result of Flow Accumulation is a raster of accumulated flow to each cell, as determined by accumulating the weight for all cells that flow into each downslope cell. Cells of undefined flow direction will only receive flow; they will not contribute to any downstream flow. A cell is considered to have an undefined flow direction if its value in the flow direction raster is anything other than $1,2,4,8,16$, 32,64 , or 128 . The accumulated flow is based on the number of cells flowing into each cell in the output raster. The current processing cell is not considered in this accumulation. Output cells with a high flow accumulation are areas of concentrated flow and can be used to identify stream channels. Output cells with a flow accumulation of zero are local topographic highs and can be used to identify ridges.

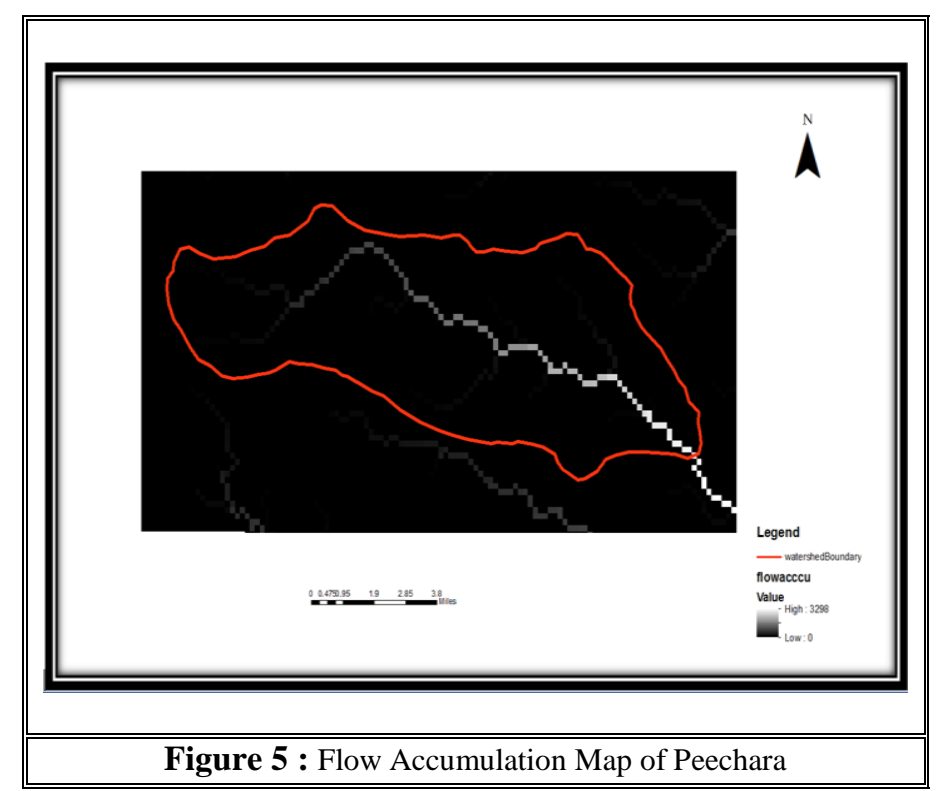




\section{Instrumentation:}

The Peechara Experimental Watershed is instrumented with soil moisture recorder and a rain gauge station as shown in Figure 7. The sensors are equipped with GSM based wireless telemetry to receive the information on real time basis at the server placed in the Institute. These data will be useful for the event based model runoff model which needs the initial moisture condition before start of rainfall event and soil moisture variation during rainfall as inputs for calculation of accurate excessive rainfall and infiltration. Installation of three water level recorders in the watershed is under progress. Digital Water level recorders are vital in measuring the observed flow at the outlet of the watershed and in the watershed and to collect information on real time basis in the Institute. Digital level sensors one at outlet of the watershed and another two inside the watershed are proposed with GSM modem. The positions of the sensors are fixed based on the stream network of the watershed as shown in Figure 6.

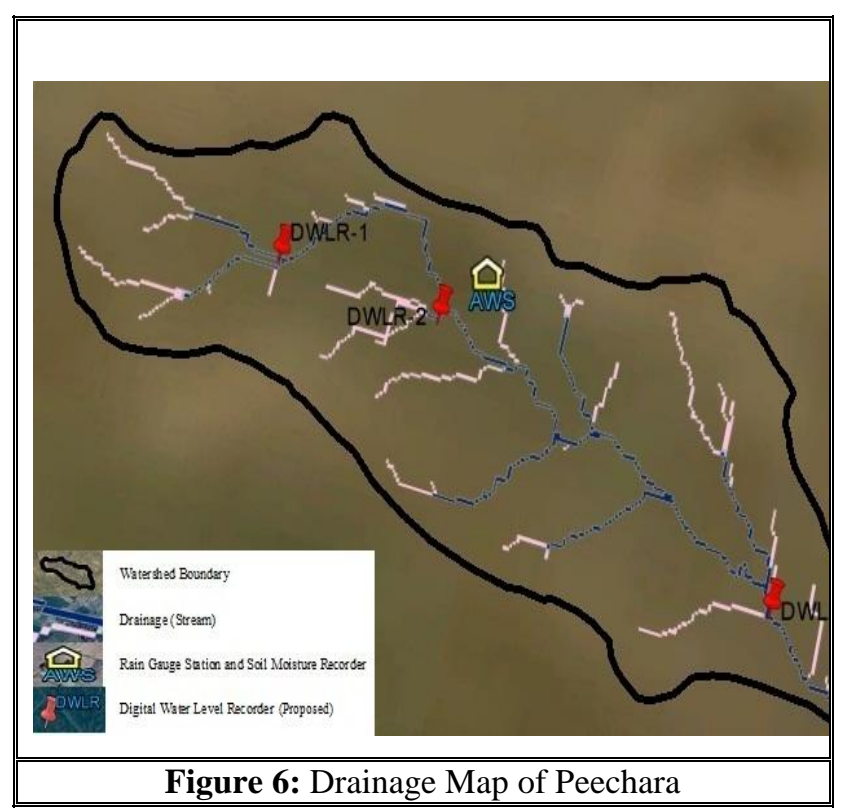

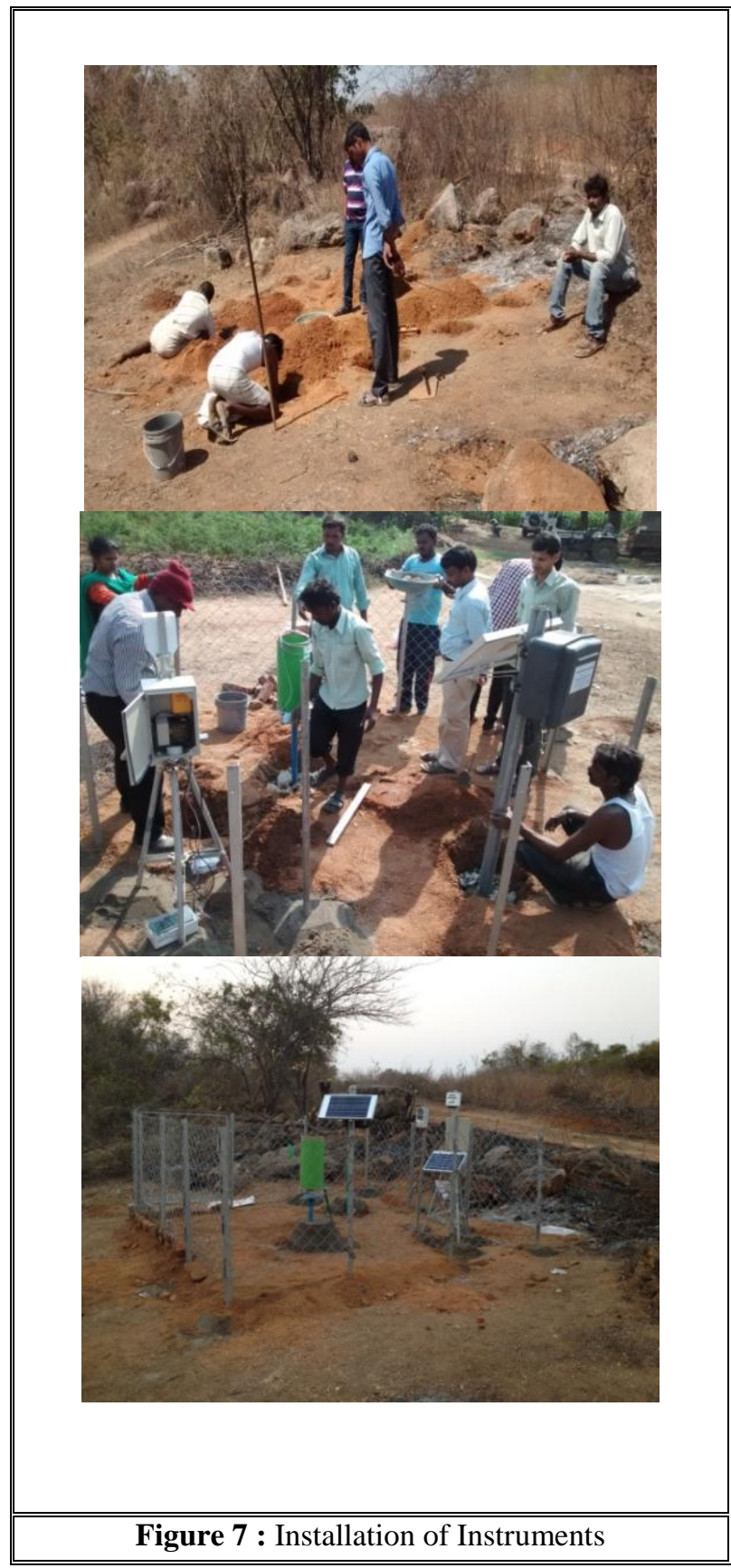

To record the soil moisture conditions, the automatic soil moisture sensor is placed in the watershed. As rainfall is a major input required for the proposed model, Automatic Rain gauge station is established at suitable location in the watershed. A GSM/GPRS based modem mechanism is placed at the weather station to send the rainfall data through telemetry to the server at the institute.

\section{Rainfall and Soil Moisture Data are downloaded on daily basis to carry out real time simulation as given in Table 1 and}

Table 2 respectively. Rainfall data is collected for every 10min interval; graph plotted for a particular day (i.e.,12.04.2015) is shown in Figure 8. Soil Moisture data is collected for every $15 \mathrm{~min}$ interval and graph plotted for a particular day (i.e., 13.04.2015) is shown in the Figure 9. 
Table 1: Rainfall Data (mm) on 12.04.2015

\begin{tabular}{|c|c|}
\hline \multirow{2}{*}{$\begin{array}{r}\text { Time } \\
\text { (min) }\end{array}$} & $\begin{array}{c}\text { Rainfall } \\
(\mathbf{m m})\end{array}$ \\
\hline & 12-04-2015 \\
\hline 00:00:00 & 0 \\
\hline 01:00:00 & 2.5 \\
\hline 02:00:00 & 0 \\
\hline 03:00:00 & 0 \\
\hline 03:30:00 & 0.25 \\
\hline 04:00:00 & 0 \\
\hline 04:10:00 & 0.25 \\
\hline 05:00:00 & 0.25 \\
\hline 05:10:00 & 0.25 \\
\hline $05: 50: 00$ & 0.25 \\
\hline 06:00:00 & 0 \\
\hline 07:00:00 & 0 \\
\hline 08:00:00 & 0 \\
\hline 09:00:00 & 0 \\
\hline 10:00:00 & 0 \\
\hline 11:00:00 & 0 \\
\hline $11: 30: 00$ & 0.25 \\
\hline 12:00:00 & 0 \\
\hline 13:00:00 & 0.25 \\
\hline 14:00:00 & 0 \\
\hline 15:00:00 & 0 \\
\hline 16:00:00 & 0 \\
\hline 17:00:00 & 0 \\
\hline 18:00:00 & 0 \\
\hline 19:00:00 & 0 \\
\hline 20:00:00 & 0 \\
\hline 21:00:00 & 0 \\
\hline 22:00:00 & 0 \\
\hline 23:00:00 & 0 \\
\hline $23: 50: 00$ & 0 \\
\hline
\end{tabular}

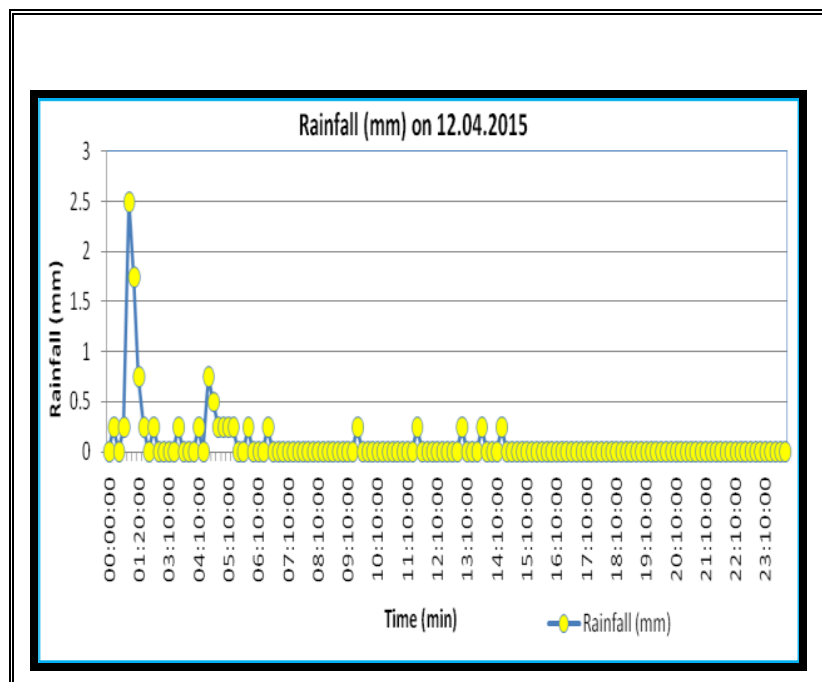

Figure 8 : Rainfall (mm) for a particular day
Table 2: Soil Moisture Data (\% of VWC) on 13.04.2015

\begin{tabular}{|c|c|}
\hline \multirow{2}{*}{$\begin{array}{c}\text { Time } \\
\text { (hr) }\end{array}$} & $\begin{array}{c}\text { Soil Moisture } \\
\text { (\% of VWC) }\end{array}$ \\
\cline { 2 - 2 } & $\mathbf{1 3 - 0 4 - 2 0 1 5}$ \\
\hline 00:00:00 & 6.2 \\
\hline 01:00:00 & 6.2 \\
\hline 02:00:00 & 6.2 \\
\hline 03:00:00 & 6.2 \\
\hline 04:00:00 & 6.3 \\
\hline $05: 00: 00$ & 6.3 \\
\hline $06: 00: 00$ & 6.4 \\
\hline $07: 00: 00$ & 11.9 \\
\hline $08: 00: 00$ & 13.2 \\
\hline $09: 00: 00$ & 11.5 \\
\hline $10: 00: 00$ & 10.8 \\
\hline $11: 00: 00$ & 10.1 \\
\hline $12: 00: 00$ & 9.7 \\
\hline $13: 00: 00$ & 9.5 \\
\hline $14: 00: 00$ & 9.2 \\
\hline $15: 00: 00$ & 8.9 \\
\hline $16: 00: 00$ & 8.9 \\
\hline $17: 00: 00$ & 8.7 \\
\hline $18: 00: 00$ & 8.5 \\
\hline $19: 00: 00$ & 8.4 \\
\hline $20: 00: 00$ & 8.2 \\
\hline $21: 00: 00$ & 8.1 \\
\hline $22: 00: 00$ & 7.8 \\
\hline $23: 00: 00$ & 7.8 \\
\hline $23: 45: 00$ & 7.7 \\
\hline & \\
\hline & \\
\hline & \\
\hline$y$
\end{tabular}

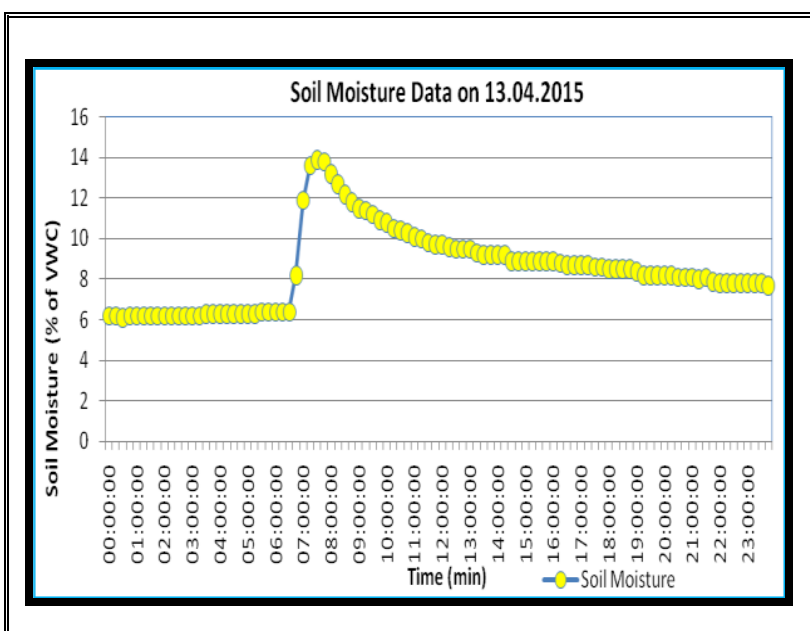

Figure 9 : Soil Moisture for a particular day

\section{Summary and Conclusions}

Present paper describes the development of an experimental watershed for real-time simulations. Preparation of various thematic maps for the watershed has been described. Rainfall and soil moisture data is plotted which is collected on daily 
basis. The developed experimental watershed is useful for accurate model forecasts and real-time simulation.

\section{ACKNOWLEDGEMENTS}

Authors are thankful to the DST-WTI, India for the financial assistance to carry out this work through project no. DST/TM/WTI/2K12/47(G). Authors are also thankful to NGO named Dalit Empowerment and Development Society (DEEDS), Warangal which is one of the implementing organizations of the watershed development projects funded by National Bank for Agriculture and Rural Development (NABARD) in Warangal District.

\section{REFERENCES}

[1] Al-Sabhan W, Mulligan M, Blackburn GA(2003) "A realtime hydrological model for flood prediction using GIS and the WWW." Computers, Environment and Urban Systems, 27, 9-32.

[2] Garcia. S(2001). "A real-time flood forecasting system based on GIS and DEM." Remote Sensing and Hydrology, IAHS Publication No. 267.

[3] Singh B.D and Ashish P (2013). " Comparative Review of Recently Developed Hydrologic Models.” Journal of Indian Water Resources Society, Vol 33, No. 3.

[4] Vieux. B.E (2002) "Vflo"T: A Real-Time Distributed Hydrologic Model." Second Federal Interagency Hydrologic Modeling Conference.

[5] Young. P (2002). "Advances in Real-Time Flood Forecasting." CRES Report Number TR/176. 